\title{
Effectiveness of Structured Teaching Programme on Knowledge and Attitude Regarding Prevention of Swine Flu among Mothers of Toddler, at Naraiyur
}

\author{
Vijayalakshmy.K $\mathbf{K}^{1}$, Chandralekha.. $\mathbf{E}^{2}$ \\ ${ }^{1}$ Assistant Professor, E S College of Nursing Villupuram \\ ${ }^{2}$ Assosciate Professor, Indrani College of Nursing, Ariyur, Puducherry \\ Corresponding Author: Vijayalakshmy.K
}

\begin{abstract}
Aim: To assess the effectiveness of structured teaching programme on knowledge and attitude regarding prevention of swine flu among mothers of toddler.
\end{abstract}

Objectives: (i) To assess the knowledge and attitude regarding prevention of swine flu among mothers of toddler. (ii)To evaluate the effectiveness of structured teaching programme on knowledge and attitude regarding prevention of swine flu among mothers of toddler. (iii)To find out the association between the post test knowledge and attitude regarding prevention of swine flu among mothers of toddler with the selected socio-demographic variables.

Methodology: A Pre experimental research design was carried out in this study. 100 samples were selected by using purposive sampling technique. The pre and post test level of knowledge was assessed by using structured knowledge questionnaires.

Results: The level of knowledge pre test mean and SD score were $12.68 \pm 1.71$ respectively and in post test mean and SD were 17.58 \pm 1.46 respectively. The calculated $t$ value was 23.1 which were greater than the tabulated value $\mathrm{p}<$ 0.005 . The level of attitude in pre test mean and SD score were $4.75 \pm 1.44$ and in post test mean and SD score were $7.95 \pm 1.52$ respectively the calculated $t$ value was 13.13 , Which was greater than the tabulated value $\mathrm{p}<0.005$. There was significant association found in number of children with level of knowledge in pre test and selected demographic variables. There was no significant association with the other demographic variables. The association between level of attitude in pre test and selected demographic data. It was statistically found that there is significance with type of family and source of information and there was no significant association with the other demographic variables.

Conclusion: The study concluded that the level of knowledge on swine flu among mothers of toddler is increased after giving a comprehensive educational package and it proved that a comprehensive educational package increases the level of knowledge.

Keywords: Comprehensive educational package

\section{INTRODUCTION}

Swine influenza is a highly contagious respiratory disease of pigs caused by one of several swine influenza viruses.

Scientists and policy makers are concerned about the emergence of an influenza pandemic for which we will have neither a strain-specific vaccine nor sufficient antiviral medications at the onset of the outbreak. In April 2009, a new strain of influenza virus, commonly referred to as "swine flu," began to spread in several countries around the world. Evidence that this new strain could pass from human to human led the World Health Organization to quickly raise its pandemic alert level to Phase 5 (29 April 2009), sending "a strong signal that a pandemic is imminent and that the time to finalize the organization, communication and implementation of the planned mitigation measures is short. On 11 
June, the alert was subsequently raised to Phase 6, indicating that a full global pandemic was underway. As of 6 August 2009, the World Health Organization reported 1,77,457 laboratory confirmed cases of influenza and 1,462 deaths. India was no exception and many deaths (138 as of 9 (September 2009) were reported in metropolitan cities such as Mumbai, Pune and Bangalore

Given the seriousness of the situation and lack of any specific vaccine against Influenza, mitigation measures in the India have so far focused on identifying, treating, and isolating people who have the disease and educating the public about the steps that individuals can take to reduce the risk of transmission. These recommendations include using tissues when sneezing, washing hands regularly with soap and water, and setting up a network of "flu friends" to provide mutual assistance when someone becomes ill. Scientists and policy makers are concerned about the emergence of an influenza pandemic for which we will have neither a strain-specific vaccine nor sufficient antiviral medications at the onset of the outbreak.

Swine flu was first reported in Mexico on 18th March, 2009 and then spread to neighbouring United States and Canada. As on 21st June 2009, World Health Organization has reported 44,287 laboratory-confirmed cases of influenza infection with 180 deaths from 94 countries spread over America, Europe, Asia and Australian continent.

The transmission of the virus is from person-to-person and is similar to the manner in which seasonal influenza spreads. The typical incubation period found for influenza is 1 to 4 days, with an average of 2 to 3 days. The symptoms of this form of virus includes sore throat, chills severe headache, coughing, weakness and general discomfort like those of influenza. However, some individuals with swine flu have shown serious respiratory illness, including pneumonia or respiratory failure leading to death. Persons suffering from chronic medical conditions like heart disease, diabetes etc., and pregnant women are at higher risk for complications from swine flu.

\section{Objectives of the Study}

1. To assess the knowledge and attitude regarding prevention of swine flu among mothers of toddler

2. To evaluate the effectiveness of structured teaching programme on knowledge and attitude regarding prevention of swine flu among mothers of toddler.

3. To find out the association between the post test knowledge and attitude regarding prevention of swine flu among mothers of toddler with the selected socio-demographic variables.

\section{Hypothesis}

H1-There will be significant difference between pre and post-test level of knowledge and attitude regarding prevention of swine flu among mothers of toddler.

$\mathrm{H} 2-$ There is a significant association between pre-test level of knowledge with their selected demographic variables.

\section{METHODOLOGY}

A Pre experimental research design study was carried out in this study. 100 samples were selected by using purposive sampling technique. The pre and post test level of knowledge was assessed by using structured knowledge questionnaires.

\section{RESULT AND DISCUSSION}

Assessment of pre and post test level of knowledge on the prevention of swine flu among mothers of toddler

Table 4.2.1: Frequency and percentage distribution of pretest
and post test level of knowledge of $\begin{gathered}\text { mothers of toddler } \\
(\mathbf{n}-100)\end{gathered}$
regarding prevention of swine flu.
\begin{tabular}{|l|c|c|c|c|}
\hline Level of knowledge & \multicolumn{2}{|c|}{ Pre test } & \multicolumn{2}{c|}{ Post test } \\
\cline { 2 - 5 } & f & $\%$ & f & $\%$ \\
\hline Inadequate & 13 & 13 & 0 & 0 \\
\hline Moderate & 87 & 87 & 11 & 11 \\
\hline Adequate & 0 & 0 & 89 & 89 \\
\hline
\end{tabular}


Vijayalakshmy.K et.al. Effectiveness of structured teaching programme on knowledge and attitude regarding prevention of swine flu among mothers of toddler, at Naraiyur

Table 4.2.1 shows that pre and post test level of knowledge among 100 mothers $13(13 \%)$ had inadequate knowledge, $87(87 \%)$ had moderate knowledge in pre

test and in post test $11(11 \%)$ had moderate knowledge, $89(89 \%)$ had adequate knowledge

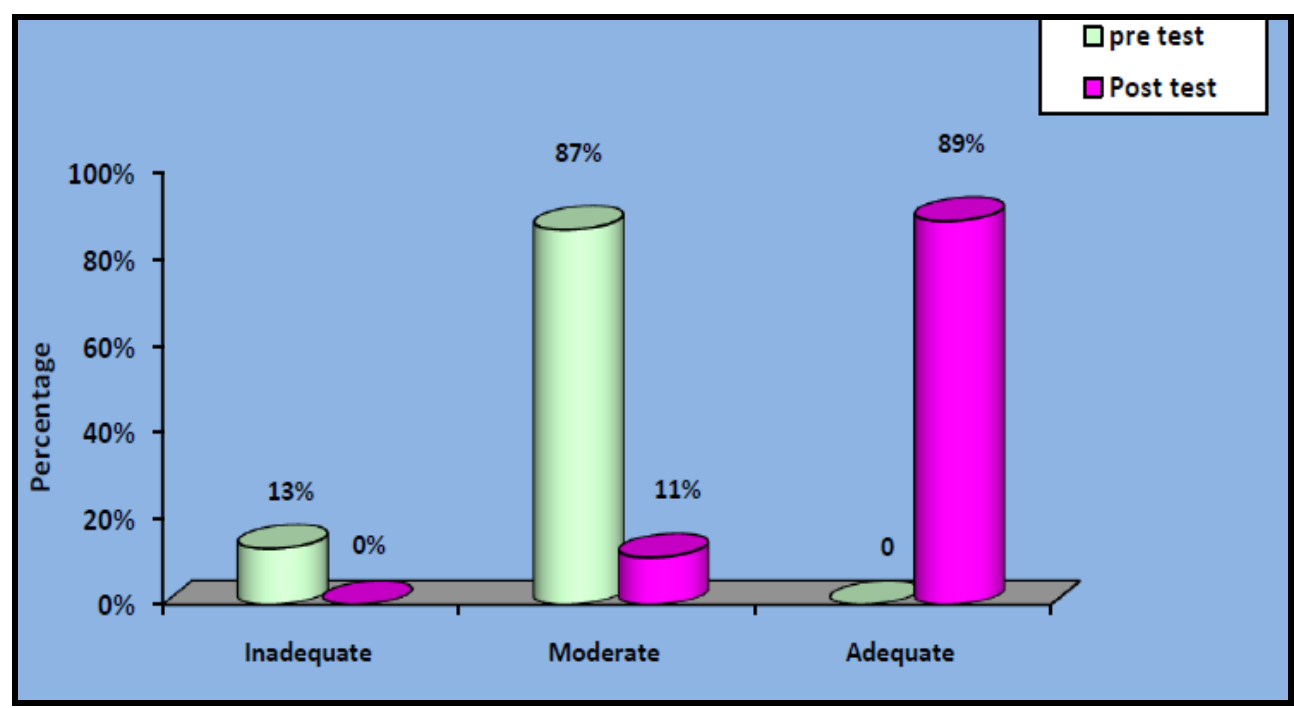

Figure 4.2.1: Frequency and percentage distribution of pre test and post test level of knowledge

Table 4.2.2: Frequency and percentage distribution pretest and post test level of attitude of mothers of toddler regarding prevention of swine flu.

\begin{tabular}{|l|c|c|c|c|}
\hline \multirow{2}{*}{ Level of attitude } & \multicolumn{2}{|c|}{ Pre test } & \multicolumn{2}{c|}{ Post test } \\
\cline { 2 - 5 } \multicolumn{1}{|c|}{ f } & \% & f & $\%$ \\
\hline Unfavorable & 71 & 71 & 8 & 8 \\
\hline Favorable & 29 & 29 & 92 & 92 \\
\hline
\end{tabular}

The above table reveals that frequency and percentage distribution to assess the effectiveness of structured teaching programme on attitude regarding prevention of swine flu (H1N1) among mothers of toddler and the results shows that most of the mothers $71(71 \%)$ had unfavorable attitude, 29(29\%) had favorable attitude in pre test and in post test $8(8 \%)$ of mothers had unfavorable attitude, 92(92\%) of mothers had favorable attitude.

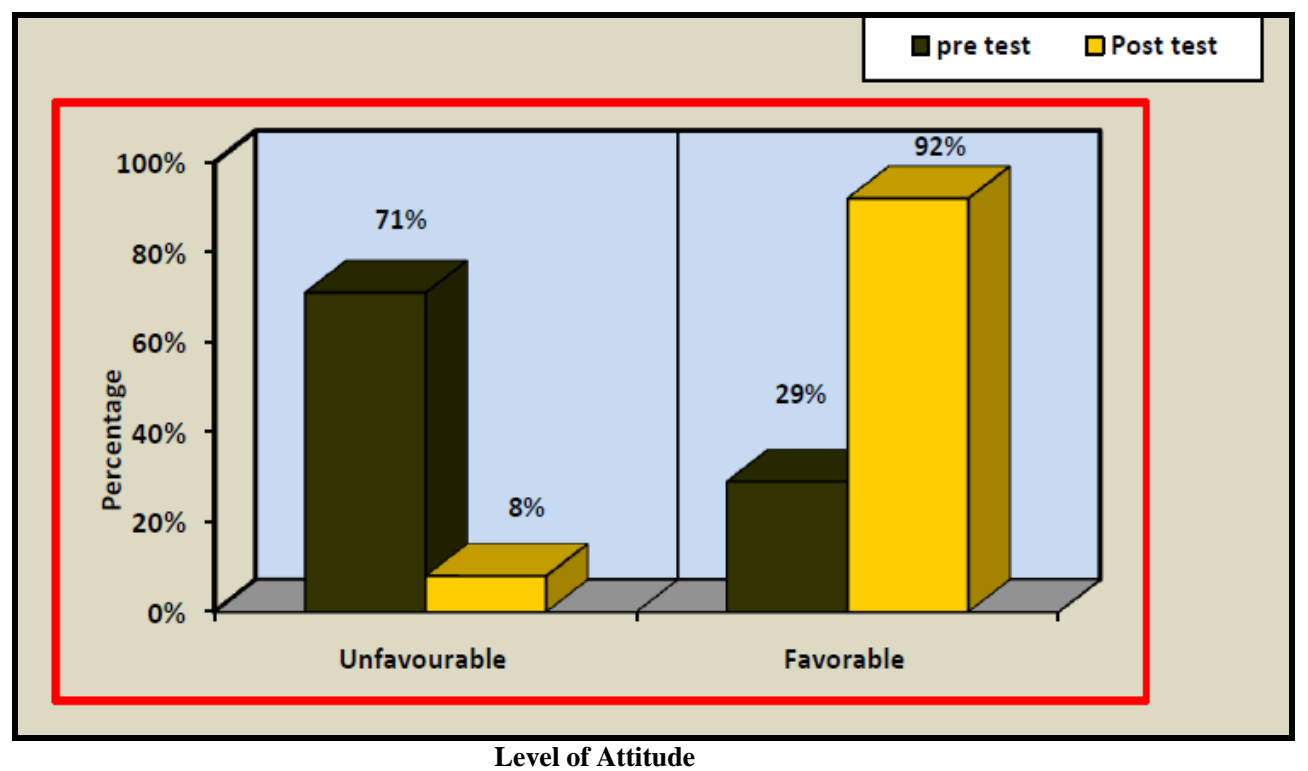

Figure 4.2.2: Frequency and percentage distribution of pretest and posttest level of attitude 
Vijayalakshmy.K et.al. Effectiveness of structured teaching programme on knowledge and attitude regarding prevention of swine flu among mothers of toddler, at Naraiyur

\section{Effectiveness of structured teaching programme on knowledge and attitude regarding prevention of swine flu among mothers of toddler}

Table 4.2.3: Effectiveness of structured teaching programme on knowledge regarding prevention of swine flu among mothers of toddler.

\begin{tabular}{|c|c|c|c|c|c|c|}
\hline \multirow{2}{*}{ Level of knowledge } & \multicolumn{2}{|c|}{ Pretest } & \multicolumn{2}{c|}{ Posttest } & t value & p value \\
\cline { 2 - 5 } & Mean & SD & Mean & SD & \multirow{2}{*}{23.11} & \multirow{2}{*}{$\mathrm{p}<0.005$} \\
\cline { 2 - 5 } & 12.68 & 1.71 & 17.58 & 1.46 & & \\
\hline
\end{tabular}

The above table represents that level of knowledge pre test mean and SD score were $12.68 \pm 1.71$ respectively and in post test mean and SD were $17.58 \pm 1.46$ respectively. The calculated t value was 23.1 which were greater than the tabulated value $\mathrm{p}<0.005$.

Table 4.2.4: Effectiveness of structured teaching programme on attitude regarding prevention of swine flu among mothers of toddler

\begin{tabular}{|c|c|c|c|c|c|c|}
\hline \multirow{2}{*}{ Level of Attitude } & \multicolumn{2}{|c|}{ Pretest } & \multicolumn{2}{c|}{ Posttest } & t value & p value \\
\cline { 2 - 5 } & Mean & SD & Mean & SD & \multirow{2}{*}{13.13} & \multirow{2}{*}{$\mathrm{p}<0.005$} \\
\cline { 2 - 5 } & 4.75 & 1.44 & 7.95 & 1.51 & & \\
\hline
\end{tabular}

The above table respectively the level of attitude in pre test mean and SD score were $4.75 \pm 1.44$ and in post test mean and SD score were $7.95 \pm 1.52$ respectively the calculated $\mathrm{t}$ value was 13.13 , Which was greater than the tabulated value $\mathrm{p}<$ 0.005 .

Association between level of knowledge in pre test and selected demographic variables

Table 4.2.5: Association between level of knowledge in pre test and selected demographic variables (n-100)

\begin{tabular}{|c|c|c|c|c|c|c|c|c|c|c|}
\hline \multirow[t]{2}{*}{ SI.No } & \multirow{2}{*}{\multicolumn{2}{|c|}{ Demographic variables }} & \multicolumn{2}{|c|}{ Inadequate } & \multicolumn{2}{|c|}{ Moderate } & \multicolumn{2}{|c|}{ Adequate } & \multirow[b]{2}{*}{$\chi^{2}$} & \multirow[t]{2}{*}{ p-value } \\
\hline & & & $\mathbf{f}$ & $\%$ & $\mathbf{f}$ & $\%$ & $\mathbf{f}$ & $\%$ & & \\
\hline \multirow[t]{4}{*}{1.} & & of mothers & & & & & & & & \\
\hline & & $21-25$ years & 5 & 5 & 36 & 36 & - & - & & \\
\hline & & 26-30 years & 8 & 8 & 42 & 42 & - & - & 1.77 & $p>0.05$ \\
\hline & & $31-35$ years & 0 & 0 & 9 & 9 & - & & & NS \\
\hline \multirow[t]{5}{*}{2.} & \multicolumn{2}{|c|}{ Educational qualification } & & & & & & & & \\
\hline & a) & Primary & 0 & 0 & 12 & 12 & - & - & \multirow{4}{*}{3.61} & \multirow{4}{*}{$\begin{array}{c}\mathrm{P}>0.05 \\
\mathrm{NS}\end{array}$} \\
\hline & & High school & 1 & 1 & 16 & 16 & - & - & & \\
\hline & & Higher secondary & 7 & 7 & 37 & 37 & - & - & & \\
\hline & & Degree & 5 & 5 & 22 & 22 & - & - & & \\
\hline \multirow[t]{5}{*}{3.} & \multicolumn{2}{|c|}{ Income } & & & & & & & & \\
\hline & a) & $5000-10000$ & 2 & 2 & 14 & 14 & - & - & \multirow{4}{*}{0.37} & \multirow{4}{*}{$\begin{array}{c}\mathrm{p}>0.05 \\
\mathrm{NS}\end{array}$} \\
\hline & b) & $10001-15000$ & 7 & 7 & 47 & 47 & - & - & & \\
\hline & c) & $15001-20000$ & 2 & 2 & 17 & 17 & - & - & & \\
\hline & & Above 20000 & 2 & 2 & 9 & 9 & - & - & & \\
\hline \multirow[t]{4}{*}{4.} & \multicolumn{2}{|c|}{ Religion } & & & & & & & & \\
\hline & & Hindu & 12 & 12 & 79 & 79 & - & - & \multirow{3}{*}{0.154} & \multirow{3}{*}{$\begin{array}{c}\mathrm{p}>0.05 \\
\mathrm{NS} \\
\end{array}$} \\
\hline & & Christian & 1 & 1 & 7 & 7 & - & - & & \\
\hline & & Muslim & 0 & 0 & 1 & 1 & - & - & & \\
\hline \multirow[t]{3}{*}{5.} & \multicolumn{2}{|c|}{ Type of family } & & & & & & & \multirow{3}{*}{0.98} & \\
\hline & & Nuclear family & 7 & 7 & 59 & 59 & - & - & & $p>0.05$ \\
\hline & & Joint family & 6 & 6 & 28 & 28 & - & - & & NS \\
\hline 6. & & idence & & & & & & & & \\
\hline & a) & Rural & 13 & 13 & 87 & 87 & - & - & & \\
\hline & & Urban & 0 & 0 & 0 & 0 & - & - & 0 & $p>0.05$ \\
\hline & & Slum & 0 & 0 & 0 & 0 & - & - & & \\
\hline 7. & & mber of children & & & & & & & & \\
\hline & a) & 1 & 4 & 4 & 3 & 3 & - & - & & \\
\hline & b) & 2 & 6 & 6 & 60 & 60 & - & - & 13.03 & $\begin{array}{l}\mathrm{p}<0.05 \\
\mathrm{~S} *\end{array}$ \\
\hline & & 3 & 3 & 3 & 24 & 24 & - & - & & \\
\hline 8. & & irce of information & & & & & & & & \\
\hline & a) & Relatives & 3 & 3 & 29 & 29 & - & - & & \\
\hline & b) & Printed media & 6 & 6 & 35 & 35 & - & - & 0.73 & $p>0.05$ \\
\hline & & Mass media & 2 & 2 & 14 & 14 & - & - & & \\
\hline & & Professionals & 2 & 2 & 9 & 9 & - & - & & \\
\hline 9. & & es of work & & & & & & & & \\
\hline & & Coolie & 3 & 3 & 39 & 39 & - & - & & \\
\hline & b) & Private & 9 & 9 & 38 & 38 & - & - & 366 & \\
\hline & c) & Government & 0 & 0 & 4 & 4 & - & - & 3.00 & $\begin{array}{c}\mathrm{p}>0.0 \mathrm{~s} \\
\mathrm{NS}\end{array}$ \\
\hline & d) & House wife & 1 & 1 & 5 & 5 & - & - & & \\
\hline & e) & Others & 0 & 0 & 1 & 1 & - & - & & \\
\hline
\end{tabular}


The above table shows that there was significant association found in number of children with level of knowledge in pre test and selected demographic variables. There was no significant association with the other demographic variables.

\begin{tabular}{|c|c|c|c|c|c|c|c|}
\hline \multirow[t]{2}{*}{ Sl. No } & \multirow[b]{2}{*}{ Demographic Variables } & \multicolumn{2}{|c|}{ Unfavorable } & \multicolumn{2}{|c|}{ Favorable } & \multirow[b]{2}{*}{$\chi^{2}$} & \multirow[t]{2}{*}{ p-value } \\
\hline & & $\mathrm{n}$ & $\%$ & $\mathrm{n}$ & $\%$ & & \\
\hline \multirow[t]{4}{*}{1.} & Age of mothers (in years) & & & & & & \\
\hline & a) 21-25 years & 29 & 29 & 12 & 12 & & \\
\hline & $26-30$ years & 35 & 35 & 15 & 15 & 0.22 & $p>0.05$ \\
\hline & c) $31-35$ years & 7 & 7 & 2 & 2 & & \\
\hline \multirow[t]{5}{*}{2.} & Educational qualification & & & & & & \\
\hline & a) $\quad$ Primary & 8 & 8 & 4 & 4 & & \\
\hline & High school & 12 & 12 & 5 & 5 & & $\mathrm{p}>0.05$ \\
\hline & Higher secondary & 32 & 32 & 12 & 12 & 0.178 & NS \\
\hline & d) Degree & 19 & 19 & 8 & 8 & & \\
\hline \multirow[t]{5}{*}{3.} & Income & & & & & & \\
\hline & a) $5000-10000$ & 9 & 9 & 7 & 7 & & \\
\hline & $10001-15000$ & 42 & 42 & 12 & 12 & 3.25 & $\mathrm{p}>0.05$ \\
\hline & $15001-20000$ & 13 & 13 & 6 & 6 & $(\mathrm{df}=3)$ & NS \\
\hline & Above 20000 & 7 & 7 & 4 & 4 & & \\
\hline \multirow[t]{4}{*}{4.} & Religion & & & & & & \\
\hline & a) Hindu & 64 & 64 & 27 & 27 & & \\
\hline & Christian & 6 & 6 & 2 & 2 & 0.49 & $\mathrm{p}>0.05$ \\
\hline & c) Muslim & 1 & 1 & 0 & 0 & & \\
\hline \multirow[t]{3}{*}{5.} & Type of family & & & & & & \\
\hline & a) Nuclear family & 52 & 52 & 14 & 14 & 5.71 & $\mathrm{P}<0.05$ \\
\hline & b) Joint family & 19 & 19 & 15 & 15 & $(\mathrm{df}=1)$ & $\mathrm{S}^{*}$ \\
\hline \multirow[t]{4}{*}{6.} & Residence & & & & & & \\
\hline & a) Rural & 71 & 71 & 29 & 29 & & \\
\hline & Urban & 0 & 0 & 0 & 0 & 0 & $\mathrm{p}>0.05$ \\
\hline & c) Slum & 0 & 0 & 0 & 0 & & \\
\hline \multirow[t]{4}{*}{7.} & Number of children & & & & & & \\
\hline & & 7 & 7 & 0 & 0 & & \\
\hline & b) & 45 & 45 & 21 & 21 & 3.12 & $\begin{array}{c}\mathrm{p}>0.05 \\
\mathrm{NS}\end{array}$ \\
\hline & c) 3 & 19 & 19 & 8 & 8 & & \\
\hline \multirow[t]{5}{*}{8.} & Source of information & & & & & & \\
\hline & a) $\quad$ Relatives & 19 & 19 & 13 & 13 & & \\
\hline & Printed media & 32 & 32 & 9 & 9 & 10.59 & $\begin{array}{c}P<0.05 \\
S *\end{array}$ \\
\hline & Mass media & 15 & 15 & 1 & 1 & & \\
\hline & d) Professionals & 5 & 5 & 6 & 6 & & \\
\hline \multirow[t]{6}{*}{9.} & Types of work & & & & & & \\
\hline & a) Coolie & 30 & 30 & 12 & 12 & & \\
\hline & Private & 32 & 32 & 15 & 15 & & \\
\hline & Government & 3 & 3 & 1 & 1 & 1.08 & $\mathrm{p}>0.05$ \\
\hline & House wife & 5 & 5 & 1 & 1 & & \\
\hline & Others & 1 & 1 & 0 & 0 & & \\
\hline
\end{tabular}

The above table result reveals the association between level of attitude in pre test and selected demographic data. It was statistically found that there is significance with type of family and source of information and there was no significant association with the other demographic variables.

\section{DISCUSSION}

First objective was to assess the knowledge and attitude regarding prevention of swine flu among mothers of toddler.

In present study shows the level of knowledge regarding prevention of swine flu (H1N1) among mothers of toddler $13(13 \%)$ had inadequate knowledge, $87(87 \%)$ had moderate knowledge in pre test and in post test $11(11 \%)$ had moderate knowledge, $89(89 \%)$ had adequate knowledge.

Second objective was to evaluate the effectiveness of structured teaching programme on knowledge and attitude regarding prevention of swine flu among mothers of toddler

In present study shows that mothers $71(71 \%)$ had unfavorable attitude, 29(29\%) had favorable attitude in pre test and in post test $8(8 \%)$ of mothers had unfavorable 
attitude, 92 (92\%) of mothers had favorable attitude.

\section{Third objective was to find out the association between the post test knowledge and attitude regarding prevention of swine flu among mothers of toddler with the selected socio- demographic variables}

The present study shows that there was significant association found in number of children with level of knowledge in pre test and selected demographic variables. There was no significant association with the other demographic variables. It also reveals the association between level of attitude in pre test and selected demographic data. It was statistically found that there is significance with type of family and source of information and there was no significant association with the other demographic variables.

\section{CONCLUSION}

The present study aim was to assess the effectiveness of structured teaching programme on knowledge and attitude regarding prevention of swine flu among mothers of toddler in a selected community area at Puducherry. The result of this study showed that there is a relationship between knowledge and attitude of mother regarding swine flu.

\section{Acknowledgement: None}

\section{Conflict of Interest: None}

\section{Source of Funding: None}

\section{Ethical Approval: Approved}

\section{REFERENCES}

1. Alan glasper, "A text book of children's and young people's nursing", $1^{\text {st }}$ edition, 2006, published by Elsevier. Pg.no.776-779

2. Helen Marry perdita, "A text book of child health nursing", 2014, published by vit med pvt, hd, Tamilnadu nurses and midwife council. Pg.no.1112-1116.

3. Mosby, "Illustrated text book of pediatrics", $3^{\text {rd }}$ edition, 2007, Published by Elsevier. Pg.no.887-991
4. Mosby, "Illustrated text book of pediatrics", $3^{\text {rd }}$ edition, 2007, Published by Elsevier. Pg.no.887-991

5. Nancy .T, "Broadribb's introductory pediatric nursing", $7^{\text {th }}$ edition, south Asian edition, 2009, published by wolters kluwer (India) pvt, Lt, New Delhi. Pg.no.562-564.

6. Parthasarathy, "IAP text book of pediatric", $4^{\text {th }}$ edition, vol.2, 2008, Jaypee brother publication. Pg.no.1012-1015.

7. Rogers', Hand book of pediatric intensive care, $1^{\text {st }}$ edition, 2009, published by wotters kluwer (India) Pvt, Ltd, New Delhi. Pg.no.1021-1024.

8. Rimple Sharma, "Essentials of pediatric nursing", 2013, Jaypee brother medical publication. Pg.no.886-889.

9. Ronald's "The normal child", $10^{\text {th }}$ edition, 2006, published by Elsevier. Pg.no.986-990.

10. SR Banerjee, "text book of community and social pediatric", $2^{\text {nd }}$ edition, 2009, Jaypee brother medical publication.Pg.no.991-996.

11. Susan Rowen James, "Nursing care of children principal and practice", $3^{\text {rd }}$ edition, 2009, published by Elsevier. Pg.no.435-437.

12. Suraj Gupte, "The short text book of pediatrics", $11^{\text {th }}$ edition, 2009, Jaypee brother medical publication.1008-1110.

\section{JOURNAL REFFERENCE:}

1. Ahrens, Pigeot, De Henauw, Lissner L, "Prevalence of swine flu below the age of 15 years ," Journal of Clinical Nursing, vol. 14, no. 4, pp. 496-500, 2014.

2. Ayele, A. Ahimed, and A. Nega, "Investigation of swine flu related complication, Ethiopia, February 2011, vol. 9, supplement 1, article P46, 2012.

3. Barkai L., I. Yildirim, M. Ceyhan et al., "Metabolic complications of swine flu during toddler," Turkish Journal of Pediatrics, vol. 50, no. 4, pp. 354-358, 2013.

4. Benkovich, B. C. Farrell, A. Nimunkar, J. Baran, and J. G. Webster, prevention of swine flu related complication, vol. 29 , no. 3 , pp. $94-$ 97, 2012.

5. Barlow SE and B. Shevchuk, "Medical evaluation of swine flu among toddlers : reports from pediatricians, pediatric nurse practitioners, and registered dietitians., chapter 9, pp. 85-92, Canadian Pharmacists Association, 2013.

6. Bailey and P. Rose, "comparison of knowledge regarding swine flu on selected urban and rural area, Victoria, Australia," Journal of Advanced Nursing, vol. 34, no. 4, pp. 465-474, 2014. 
7. Chaturvedi, K. Y. Vilhekar, P. Chaturvedi, and M. S. Bharambe, "Child behaviors associated with swine flu and parents selfefficacy to handle children," Indian Pediatrics, vol. 41, no. 6, pp. 600-603, 2013.

8. Craig, G. A. Lancaster, P. R. Williamson, and R. L. Smyth, "Community and family perspectives on addressing swine flu in urban," The British Medical Journal, vol. 320, no. 7243, pp. 1174-1178, 2015.

9. Chung and C. Chen, "Evaluation of swine flu in children," vol. 10, no. 4, pp. 3073-3089, 2010.

10. Dolkar, S. Kapoor, N. V. Singh, and V. Suri, "A comparative study on knowledge and attitude swine flu," Nursing and Midwifery Research, vol. 9, no. 1, pp. 40-46, 2014.

11. Davies, J. Y. Kassab, A. J. Thrush, "cytokine signaling 3 gene polymorphisms in swine flu toddler.," Journal of Advanced Nursing, vol. 11, no. 5, pp. 535-543, 2015.

12. Fadzil, D. Choon, and K. Arumugam, "A comparative study on knowledge regarding prevention of swine flu," Australian Family Physician, vol. 39, no. 4, pp. 237-239, 2013.

13. Fulbrook, "prevention of swine flu," Journal of advanced nursing, vol. 18, no. 9, pp. 14511460, 2014.

14. Geyer C, M. J. Viljoen, and G. Joubert, "Designing and implementing teachers' training sessions in a kindergarten-based, family-involved intervention to prevent swine flu early childhood, vol. 23, no. 3, pp. 54-61, 2013.

15. Gasim, I. R. Musa, M. T. Abdien, and I. Adam, "Comparison of knowledge and attitude regarding prevention of swine flu" Notes, vol. 6, no. 1, article 194, 2015.

16. Holtzclaw, Moschonis G, Kalliora AC, "Identification of lifestyle patterns associated with prevention of swineflu," Biological Research for Nursing, vol. 2, no. 4, pp. 221235, 2013.

17. Hennink M, Comeau D, Welsh JA and Hardy $\mathrm{T}$, "prevention of swine flu" Friend of Chemical Industry, no. 29, pp. 20-21, 2015.

18. Imani, S. Salehi, R. Habibian, B. Sadeghi, and K. Hatamipour, "Comparative study of swine flu on urban and rural knowledge and attitude level of prevention of swine flu.," Iran Journal of Nursing, vol. 21, no. 56, pp. 9-16, 2014.

19. J Clin Res Pediatric Endocrinal "prevention of swine flu," the State of India's Children, pp. 65-71, NNF India, New Delhi, India, 2016.
20. Latman, P. Hans, L. Nicholson, K. Lewis, and A. Shirey, "Evaluation of An assessment of practices and attitude swine flu," vol. 35, no. 4, pp. 259-265, 2014.

21. Lawson, Marks J, Barnett, Allender et al., "Change of swine flu, Australia, vol. 16, no. 5, pp. 485-496, 2014.

22. Lam, and K. Chow, "swine flu prevention," Hong Kong Medical Journal, vol. 8, no.1, article 39, 2012.

23. Lin, and Chuang, "Evaluation protocol to assess an integrated framework for the implementation of the swine flu Research Demonstration project at the California (CACORD) and Massachusetts (MA-CORD) sites.," Journal of Henan University (Medical Science), vol. 31, no. 1, pp. 53-54, 2014.

24. McCallum and D. Higgins, "assessing the swine flu in children," Nursing Times, vol. 108, no. 45, pp. 20-22, 2012.

25. Peterson CB, Crosby RD, Rydell SA et al., "Overeating phenotypes in swine flu," Pediatric Emergency Care, vol. 23, no. 1, pp. 16-19, 2014.

26. Redsell SA, Atkinson PJ, F. S. Jensen, "Preventing swine flu during infancy in UK primary care," British Journal of nursing, vol. 166, no. 11, pp. 848-851, 2015. Rosenthal and A. Leslie, "assess the attitude on swine flu, a comparison of three devices," Journal of pediatricl Nursing, vol. 12 , no. 4, pp. 125129, 2015.

27. Rahman, F. B. Kasem, MR. Islam, and A. Matin, "swine flu prevention, vol. 4, no. 2, pp. 60-61, 2013.

28. Radhi and W. Barry, "assessment of swine flu in community," Archives of Disease in Childhood, vol. 91, no. 4, pp. 351-356, 2012.

29. Rito AI, Lissner L and Duleva, "WHO European swine flu prevention Surveillance Initiative", BMC public health, vol. 29, no. 2, pp. 117-125, 2015.

How to cite this article: Vijayalakshmy.K, Chandralekha.E. Effectiveness of structured teaching programme on knowledge and attitude regarding prevention of swine flu among mothers of toddler, at Naraiyur. Galore International Journal of Applied Sciences \& Humanities. 2021; 5(4): 1-7. DOI: https:// doi.org/10.52403/gijash.20211001 